\title{
Increasing production of integration system of corn and beef cattle in Gowa, South Sulawesi
}

\author{
Lu'ulul Amna*, Matheus Sariubang, and Andi Nurhayu \\ South Sulawesi Assessment Institute of Agriculture Technology South Sulawesi, Makassar, South \\ Sulawesi, Indonesia
}

\begin{abstract}
An integrated bioindustry agricultural system of sustainable bioindustrial agricultural system based on the integration of corn and beef cattle has been developed in Gowa Experimental Station, The Assessment Institute of Agriculture Technology South Sulawesi. The aim of this study was to build a waste-free agricultural system, using minimum input of production and energy from outside, the biomass and waste processing system into new high-value, environmentally friendly bio-products. Implementation stages consisted of two parts i.e., corn planting, and maintenance of beef cattle. Corn was planted on area of 1.5 ha by implementing Integrated Crop Management, while eighteen cows were used which were divided into three treatments with six replications. A completely randomized design was used in the study. The results indicated that the integration of corn-beef cattle at the Experimental Station was able to produce 5 tons/ha of shelled corn. Corn straw produced was as much as $3751 \mathrm{~kg} / \mathrm{ha}$ and corn cob up to $1289 \mathrm{~kg} / \mathrm{ha}$ for animal feed. The use of fermented corn straw and corn cob as a concentrate was able to increase body weight of cattle by $0.28 \mathrm{~kg} / \mathrm{head} /$ day. The integration of corn-beef cattle based on bioindustry is potential to increase corn production and improve performance of beef cattle.
\end{abstract}

\section{Introduction}

Sustainable agricultural development (including rural development) is a strategically important issue that is of concern and discussion in all countries today. Sustainable agricultural development is not only a goal, but also a paradigm for agricultural development [1].

Sustainable bioindustry is a bioindustry that meets the requirements of sustainable economic activities in general [2]. The main characteristic of sustainable bioindustry is to apply the 3R principles: reduce, reuse and recycle. The concept of sustainable agricultural bioindustry is to integrate food crops with livestock. Plant-livestock integration system is an agricultural system characterized by a close relationship between plant and livestock components in a farm or in an area. This linkage is a triggering factor in encouraging the income growth of farming communities and regional economic growth in a sustainable way. Through the concept of zero waste agriculture, livestock waste can be used as compost, bio

* Corresponding author: luulul.amns@gmail.com 
gas, and bio urine. In contrast, agricultural waste is converted into feed and other derivative products [3].

Crop-livestock integration is a model of sustainable bio-industrial agriculture. The concept of bioindustrial agriculture refers to an ecological approach that is not exploitative. Crop-livestock integration system is environmentally friendly and sustainable by integrating rainfed rice crops, livestock management, livestock manure management for biogas and organic fertilizers, and environmentally friendly technology components such as the manufacture of charcoal to reduce residues of agrochemicals (pesticides, fertilizers, heavy metals) which uses biogas as fuel [4].

Corn has a very strategic utility, both in the food security system and its role as a driving force for national economy. Corn is used as food, feed, fuel, and polymer. The demand for corn for food, feed and other industrial needs in the next five years is projected to continue to increase in line with the increasing population [5]. Based on the report of the Ministry of Agriculture's Data and Information System, national corn planted area for period October 2019 - September 2020 reached 5.5 million hectares. National corn harvested area from January to December 2020 reached 5.16 million hectares. The first order is East Java with a harvested area of 11.9 million hectares producing 5.37 million tons. South Sulawesi is in fifth place with a harvested area of 377.7 thousand hectares producing 1.82 million tons [6]. Besides being known as a corn producer, South Sulawesi is the largest center for beef cattle development outside Java. The beef cattle population in Indonesia has reached 17,466,792 heads, and beef cattle population in South Sulawesi has reached 1,431,533 heads [7]. Large potential of corn and beef cattle in Indonesia, especially in South Sulawesi, will have an impact on the production of very large amounts of biomass waste. Proper management and utilization of biomass waste is needed to support zero waste agriculture and bioindustry in a sustainable way, while preventing the impact of environmental pollution and the effects of greenhouse gas emissions that can damage the ozone layer.

The aim of this study was to build a zero-waste agricultural system, using minimal inputs of production and energy from outside the system, processing biomass and waste into new bio-products of high value and environmentally friendly.

\section{Materials and methods}

This study was carried out at Gowa Experimental Station, The Assessment Institute of Agriculture Technology South Sulawesi in Pa'bentengan Village, Bajeng District, Gowa Regency. Stages of implementing the activity consist of two parts, i.e., 1) Corn planting and 2) Maintenance of beef cattle. The components of hybrid corn technology used in this study is presented in Table 1.

Table 1. Hybrid corn technology components.

\begin{tabular}{|c|c|}
\hline Technology components & Description \\
\hline Superior varieties & Bisi 18 \\
\hline Soil Cultivation & No tillage \\
\hline Planting system & Monoculture \\
\hline Planting distance & $75 \times 25 \mathrm{~cm}$ \\
\hline Number of planting hole seeds & 1 seed \\
\hline Fertilization method & Tugal 3 times \\
\hline Weeding & 2 times \\
\hline Disease pest control & Integrated pest control \\
\hline Harvest system & Manual \\
\hline
\end{tabular}


Corn planting was carried out on an area of 1.5 ha using hybrid corn seeds of Bisi 18 variety. Fertilizer doses for corn were urea $300 \mathrm{~kg} / \mathrm{ha}, \mathrm{SP}-36100 \mathrm{~kg} / \mathrm{ha}, \mathrm{KCL} 50 \mathrm{~kg} / \mathrm{ha}$ and manure (organic) $2,000 \mathrm{~kg} / \mathrm{ha}$ before planting.

Corn waste in the form of straw was used as feed for eighteen cows which were divided into three feed treatments each with six replications, namely:

P1 : Fermented corn straw 50\% + fresh elephant grass $50 \%+$ concentrate 2 $\mathrm{kg} / \mathrm{head} /$ day.

P2 : Non-fermented corn straw 50\% + fresh elephant grass $50 \%+$ concentrate 2 $\mathrm{kg} / \mathrm{head} / \mathrm{day}$.

P3 : Fresh elephant grass $100 \%$ + concentrate $2 \mathrm{~kg} / \mathrm{head} /$ day.

The concentrate used consisted of a mixture of bran, corn cob flour, milled corn, fish meal, coconut cake, pikuten, and salt. Table 2 shows the percentage of concentrate formulation given to cows.

Table 2. Concentrate formulation.

\begin{tabular}{|l|c|}
\hline \multicolumn{1}{|c|}{ Composition } & Percentage \\
\hline Bran & 50 \\
\hline Corn cob flour & 10 \\
\hline Ground corn & 19 \\
\hline Fish flour & 10 \\
\hline Coconut meal & 10 \\
\hline Pikuten & 0.5 \\
\hline Salt & 0.5 \\
\hline Total & 100 \\
\hline
\end{tabular}

Giving forage is $10 \%$ of body weight. Drinking water is provided at libitum. Feed and feed residues were weighed daily. The study was conducted by providing treatment rations during the maintenance period for 3 months. Body weight gain data was designed using a completely randomized design [8]. Data obtained were analyzed by analysis of variance (ANOVA), using the General Linear Model procedure according to SPSS instructions (version 23). If the results of the variance analysis show a significant effect, it will be continued with Duncan's multiple distance test [9].

\section{Results and discussion}

\subsection{Corn planting and potential corn waste}

Hybrid corn plantations on an area of 1.5 ha apply the integrated crop management which has been developed by the Indonesian Agency for Agricultural Research and Development. Integrated crop management is very helpful to prioritize increasing yield productivity, facilitating pest and disease control, using fertilizer more efficiently, and increasing farm income [10]. Technology components defined in integrated crop management are grouped into basic and optional technologies. Basic technology components implemented are: (1) New superior varieties, hybrids or composites, (2) Quality and labeled seeds, (3) Population 66,000-75,000 plants/ha, (4) Fertilization based on plant needs and soil nutrient status [11].

Corn planting at Gowa Experimental Station used manure from cow waste treatment of 2 tons/ha which was given before planting. The use of manure was aimed to improve soil structure before planting corn. This is in accordance with what was stated by Septian et al. [12], that the use of organic materials such as cow dung compost is useful for repairing damaged soil structures due to excessive use of chemical fertilizers. More Basuni et al. [13] 
argues that the addition of organic fertilizers can reduce the use of urea by $71.43 \%$, TSP $50 \%$, and $\mathrm{KCl} 50 \%$ per growing season.

The average yield of shelled corn before integration was $4200 \mathrm{~kg} / \mathrm{ha}$ and after integration increased to $5000 \mathrm{~kg} / \mathrm{ha}$. Corn production had increased by $800 \mathrm{~kg} / \mathrm{ha}$. However, this result was still lower than that of Mustikawati and Pujiharti [14] which shows the dry shelled production of Bima variety reached $5.66 \mathrm{t} / \mathrm{ha}$ dry shelled production. This is probably due to the long dry season at the time of planting corn and the presence of rat pests that often hit the corn plantations at Gowa Experimental Station so that corn production is lower. Comparison of hybrid corn waste production before and after integration can be seen in Table 3 .

Table 3. Production of hybrid corn waste before and after integration $(\mathrm{kg} / \mathrm{ha})$

\begin{tabular}{|l|c|c|}
\hline \multicolumn{1}{|c|}{ Production } & Before integration & After integration \\
\hline Corn straw $(\mathrm{kg} / \mathrm{ha})$ & 3000 & 3751 \\
\hline Corn cob $(\mathrm{kg} / \mathrm{ha})$ & 1100 & 1280 \\
\hline Corn husk $(\mathrm{kg} / \mathrm{ha})$ & 1500 & 1600 \\
\hline
\end{tabular}

The results of hybrid corn waste production that can be used as feed were corn straws, corn cobs and corn husk. Corn straw/stover is part of the stems and leaves of corn that have been dried in the field and are harvested when the corn cobs are picked. This kind of corn straw is mostly obtained in the center area of corn plantations with the aim of producing corn seeds or corn for feed industry, not for consumption as vegetables [15]. Corn straw production before integration was $3000 \mathrm{~kg} / \mathrm{ha}$ and after integration increased up to 3751 $\mathrm{kg} / \mathrm{ha}$. The increase in corn straw production was due to the increase in corn production. Corn cobs are waste obtained when corn kernels are threshed from fruit. Shelled corn is the main product and the rest of the fruit called cobs or janggel [16]. Corn cobs also increased after integration, up to $1280 \mathrm{~kg} / \mathrm{ha}$ where before integration was $1100 \mathrm{~kg} / \mathrm{ha}$. Corn husk/klobot is the outer skin of corn fruit that is usually discarded [15]. Corn husk is very potential to be used as silage because the sugar content is quite high. Corn husk production before integration was $1500 \mathrm{~kg} / \mathrm{ha}$ and after integration increased to $1600 \mathrm{~kg} / \mathrm{ha}$.

The results of corn straw proximate analysis on integration activities of corn-beef cattle can be seen on table 4 .

Table 4. Corn straw proximate analysis corn-beef cattle integration in Gowa Experimental Station

\begin{tabular}{|l|c|c|}
\hline \multicolumn{1}{|c|}{ Parameters } & $\begin{array}{c}\text { Fresh corn } \\
\text { straw }\end{array}$ & $\begin{array}{c}\text { Fermented } \\
\text { corn straw }\end{array}$ \\
\hline Crude protein (\%) & 5.56 & 10.25 \\
\hline Crude fat (\%) & 1.25 & 4.0 \\
\hline Crude fiber (\%) & 33.58 & 24.29 \\
\hline Ash (\%) & 7.28 & 11.10 \\
\hline BETN (\%) & 50.20 & 27.67 \\
\hline Ca (\%) & 0.5 & 0.37 \\
\hline
\end{tabular}

Source: Laboratory Analysis. Animal Feed Nutrition, Faculty of Animal Husbandry, Hasanuddin University, 2017.

The results of the proximate analysis before and after fermentation (Table 4) showed that the nutrient content of corn straw increased after fermentation. Crude protein content before fermentation was $5.56 \%$ increased to $10.25 \%$ after fermentation. Crude fiber content decreased from $33.58 \%$ to $24.19 \%$. An increase in protein and a decrease in crude fiber content is very supportive in its use as animal feed, because in general the limiting factor in the use of agricultural waste as animal feed is the low nutritional value. 


\subsection{Cattle waste potential}

Gowa Experimental Station has great potential to become a center for beef cattle breeding with a bio-industry-based agricultural concept in South Sulawesi. Besides having a fairly large area of land, it also has a large number of beef cattle, namely 249 heads [17]. The model for breeding beef cattle at Gowa Experimental Station is integrated with food crops (corn) and will apply technological innovations by Indonesian Agency for Agricultural Research and Development so that it can increase the value of production for cattle, such as producing quality calf, increasing food production, increasing raw materials for bio-industry and bioenergy.

By-product of the cattle breeding process is recycling the use of cow manure through fermentation into quality compost. The number of cows in the integration of corn-beef cattle based on bioindustry at Gowa Experimental Station is 18 heads, if one cow every day produces feces (dung) ranging from $8-10 \mathrm{~kg}$ per day or $2.8-3.6$ tons per year or equivalent with 1.5-2 tons of organic fertilizer, the integration of corn-beef cattle based on bioindustry is able to produce manure as much as 50.4 tons/year to 64.8 tons/year [18]. The need for manure for corn land itself is 2 tons/ha, besides being used for corn plants, manure is also used for other crops in the Experimental Station, such as planting rice, citronella, forage grass and others. The content of compost used can be seen in Table 5.

Table 5. Compost organic fertilizer content in Gowa Experimental Station.

\begin{tabular}{|c|c|}
\hline Nutrient & Results \\
\hline N-total (\%) & 2.78 \\
\hline $\mathrm{P}_{2} \mathrm{O}_{5}(\%)$ & 0.89 \\
\hline $\mathrm{K}_{2} \mathrm{O}(\%)$ & 2.11 \\
\hline $\mathrm{pH}(\%)$ & 8.01 \\
\hline C-Organik (\%) & 14.50 \\
\hline Water content (\%) & 20.11 \\
\hline $\mathrm{C} / \mathrm{N}$ & 5 \\
\hline $\mathrm{Fe}, \mathrm{ppm}$ & 8261 \\
\hline $\mathrm{Mn}, \mathrm{ppm}$ & 3711 \\
\hline $\mathrm{Cu}, \mathrm{ppm}$ & 98 \\
\hline $\mathrm{Zn}, \mathrm{ppm}$ & 116 \\
\hline $\mathrm{Pb}, \mathrm{ppm}$ & 20 \\
\hline $\mathrm{Cd}, \mathrm{ppm}$ & $\mathrm{Tt}$ \\
\hline
\end{tabular}

Source: Maros Installation Laboratory, 2018.

The results of manure analysis showed that the total $\mathrm{N}$ of $2.78 \%$ was a fairly good value above the SNI 19-7030-2004 standard with a nitrogen value of $>0.40 \%$ [19]. The content of P205 is 0.89 above the SNI standard of $>0.10 \%$. According to Stofella and Khan [20] that element $\mathrm{P}$ is needed by microorganisms to build their cells such as protoplasm and cell nuclei. The C-Organic content of $14.50 \%$ also meets the standards of SNI 19-7030-2004 (9.8-32\%). The $\mathrm{C} / \mathrm{N}$ ratio value of 5\% is still below the standard of SNI 19-7030-2004, namely (10$20 \%$ ). The $\mathrm{pH}$ value of 8.01 is slightly higher than according to SNI 19-7030-2004 (6.8-7.49).

\subsection{Utilization of corn straw as beef cattle feed}

The potential of corn straw is quite abundant, but it has not been used as cattle feed. The main obstacle to the use of corn straw as animal feed is the high crude fiber and protein content 
and low digestibility. The use of corn straw directly or as a sole feed cannot meet the supply of nutrients needed by livestock [21]. Quality of corn straw can be increased by biological treatment such as fermentation, due to the involvement of microorganisms in degrading crude fiber, reducing levels of lignin and anti-nutrient compounds, so that the digestibility value of feed from waste such as rice straw can increase [22].

Production of corn waste from the integration activities of corn-beef cattle at Gowa Experimental Station is $3751 \mathrm{~kg} / \mathrm{ha}$ corn straw, $1280 \mathrm{~kg} / \mathrm{ha}$ corn cobs and $1600 \mathrm{~kg} / \mathrm{ha}$ corn husks (Table 4). Before being used as feed, corn straw is fermented to increase protein value, reduce crude fiber and increase digestibility value. Corn straw fermentation is a process of overhauling a complex structure so that it becomes simpler, and this causes the digestibility of livestock to be more efficient [23]. After the fermentation process, corn straw is given to the cow as a substitute for elephant grass to improve the condition of cow's body and help the growth of the calf.

Analysis of variance showed that the administration of fermented corn straw as a substitute for elephant grass had a significant effect $(\mathrm{P}<0.05)$ on the average daily body weight gain of cows. Duncan's test (Table 6) showed that treatment P1 was significantly higher than treatment P2 and P3, while treatment P2 was significantly lower than other treatments but not significantly different from P3. These results indicate that cows fed fermented corn straw feed gave better daily body weight gain than those given unfermented corn straw and cows fed only elephant grass without corn straw. The increase in body weight was due to the nutritional content of fermented corn straw combined with elephant grass plus concentrate according to the needs of the cow so that the performance was much better. This is in accordance with the results of research by Mastika and Puger [24] that feed quality is a factor that greatly determines the growth and quality of meat. Improving the quality of feed, even though it comes from waste, was able to increase body weight gain better than that given by field grass. Improvement of feed for cows at Gowa Experimental Station by providing fermented corn straw plus concentrate as a feed supplement has a positive impact on calf growth. This is in accordance with what was stated by Rohmah et al. [25], that supplementation is in the form of feed that contains sufficient nutrients to support the production and reproduction of beef cattle so that the cow are ready to carry out the reproductive process, including pregnancy, giving birth and breastfeeding calves. Improving the body condition of beef cows before mating can optimize the livestock reproduction process so that it can reduce the number of repeated matings.

Table 6. The average body weight gain of cows in the Corn-Beef Cattle Integration at Gowa Experimental Station

\begin{tabular}{|l|c|c|c|}
\hline \multirow{2}{*}{\multicolumn{1}{|c|}{ Description }} & \multicolumn{3}{|c|}{ Treatments } \\
\cline { 2 - 4 } & P1 & P2 & P3 \\
\hline Initial weight $(\mathrm{kg} /$ head/day) & 170.1 & 169.5 & 170.5 \\
\hline Final weight $(\mathrm{kg} / \mathrm{head} /$ day) & 195.6 & 186.8 & 191.3 \\
\hline Daily weight gain $(\mathrm{kg} / \mathrm{head} /$ day) & $0.28^{\mathrm{b}}$ & $0.19^{\mathrm{a}}$ & $0.23^{\mathrm{a}}$ \\
\hline
\end{tabular}

$\mathrm{P} 1=$ fermented corn straw $50 \%+$ fresh elephant grass $50 \%+$ concentrate $2 \mathrm{~kg} / \mathrm{head} / \mathrm{day} ; \mathrm{P} 2=$ nonfermented corn straw $50 \%+$ fresh elephant grass $50 \%+$ concentrate $2 \mathrm{~kg} / \mathrm{head} /$ day; $\mathrm{P} 3=$ fresh elephant grass $100 \%+$ concentrate $2 \mathrm{~kg} / \mathrm{head} /$ day. Superscripts following the same values on the same line showed significant differences $(\mathrm{P}<0.05)$.

\section{Conclusions}

Base on this study, it can be concluded that corn-beef cattle system integration model based on agricultural bioindustry at Gowa Experimental Station can increase corn production (5000 $\mathrm{kg} / \mathrm{ha})$ and can improve the performance of cows $(0.28 \mathrm{~kg} / \mathrm{head} /$ day $)$ and livestock waste into organic fertilizer to increase soil fertility. 


\section{References}

1. R.S. Rivai, I.S. Anugrah, Jur. Forum Penelitian Agro Ekonomi, 29, 2, 13-25 (2011)

2. P. Simatupang, Perspektif system pertanian bioindustri berkelanjutan, $\mathrm{http} ; / / \mathrm{www}$. litbang.pertanian.go.id/buku/reformasi-kebijakan, (2015)

3. Suswono, Sektor pertanian akan menjadi bioindustri, http://www.ekonomy.okezone.com (2014)

4. Balingtan, Sistem integrasi tanaman ternak ramah lingkungan, Balai Penelitian Lingkungan Pertanian, Badan Penelitian dan Pengembangan Peternakan, Kementerian Pertanian (2013)

5. A. Ilyas, Maintang, Pengelolaan tanaman jagung zero waste mendukung pertanian bioindustry berkelanjutan, in Prosiding Seminar Nasional Serealia Balai Penelitian Serealia, Badan Penelitian dan Pengembangan Pertanian Kementerian Pertanian, 256263 (2015)

6. K.A. Pragotsa, National corn production exceeds the Indonesian govt's target, https://www.berita2bahasa.com/ (2021)

7. BPS, Indonesia dalam angka, https://www.bps.go.id/ (2020)

8. R.G.D. Steel, J.H. Torrie, Prinsip dan prosedur statistika: suatu pendekatan biometric, translated from: Principles and Procedures of Statistic,Gramedia, Jakarta (1993)

9. M. Kaps, W.R. Lamberson, Biostatistic for animal science, CABI Publishing, Cambridge, USA (2004)

10. R. Rosadillah, A. Fatchiya, D. Susanto, Jur. Penyuluhan, 13, 2, 143-156 (2017)

11. I.M.D Mejaya, T. Ratule, Zubachtirodin, S. Saenong, M.S. Pabbage, M. Azrai, D. Setyorini, S. Kartaatmadja, F. Kasim, Pedoman umum PTT jagung, Pusat Penelitian dan Pengembangan Tanaman Pangan, Badan Penelitian dan Pengembangan Pertanian, Departemen Pertanian, Bogor, Indonesia (2016)

12. N.A.W. Septian, N. Aini, N. Herlina, Jur. Prod. Tanaman, 3, 2, 141-148 (2015)

13. R. Basuni, Muladno, C. Kusmana, Suryahadi, Forum Pascasarjana, 33, 3, 177-190 (2010)

14. D.R. Mustikawati, Y. Pujiharti, Introduksi varietas unggul jagung komposit di Lampung, in Seminar Nasional Serealia Badan Penelitian dan Pengembangan Teknologi Pertanian Kementerian Pertanian, 134-142, (2011)

15. Mariyono, U. Umiyasih, Y. Anggraeny, M. Zulbardi, Pengaruh substitusi konsentrat komersial dengan tumpi jagung terhadap performans sapi PO bunting muda, in Prosiding Seminar Nasional Teknologi Peternakan dan Veteriner, 4-5 Agustus 2004, Bogor, Indonesia (2004)

16. S. Bahar, Buletin pertanian kota, 6, 2, 25-31 (2016)

17. A. Nurhayu, M. Sariubang, Inovasi teknologi spesifik lokasi mendukung peningkatan produksi padi di Sulawesi Selatan, in Bunga Rampai, Balai Pengkajian Teknologi Pertanian Sulawesi Selatan, Balai Besar Pengkajian dan Pengembangan Teknologi Pertanian, Badan Penelitian dan Pengembangan Pertanian, Kementerian Pertanian, 114131 (2019)

18. M. Sariubang, A. Nurhayu, A. Ella, N. Qomariyah, D. Pasambe, Model pembibitan sapi potong mendukung pertanian bioindustri berkelanjutan di KP Gowa Sulawesi Selatan, in Laporan Tahunan Balai Pengkajian Teknologi Pertanian Sulawesi Selatan, Balai Besar Pengkajian dan Pengembangan Teknologi Pertanian, Badan Penelitian dan Pengembangan Pertanian, Kementerian Pertanian (2017)

19. T.P.T.N. Tantri, A.A.N. Supadma, I.D.M Arthagama, E-Jur. Agroekotek. Trop. 5, 1, $52-$ $62(2016)$

20. P.J. Stofella, B.A. Khan, Compost utilization in holticultural cropping system, Lewis Publishers, USA (2001) 
21. Yunilas, Bioteknologi jerami padi melalui fermentasi sebagai bahan pakan ternak ruminansia, in Karya Ilmiah Departemen Peternakan Fakultas Pertanian Universitas Sumatera Utara, Medan, Indonesia (2009)

22. D. Riayatsyah, Evaluasi kualitas nutrisi ampas tebu amoniasi yang difermentasi menggunakan Trichoderma harzianum dengan lama pemeraman berbeda, Program Studi Peternakan Fakultas Pertanian Universitas Syiah Kuala, Banda Aceh, Indonesia (2015)

23. FAO, Jerami fermentasi sebagai pakan alternative bagi ternak sapi pada musim kemarau, http://database-deptango.id.sains,indonesia/index,php? files $=$ DetailTechnologies indo\&id=83 (2009)

24. I.M. Mastika, A.W. Puger, Upaya perbaikan penampilan (performance) Sapi Bali melalui perbaikan ketersediaan dan kualitas pakan Fakultas Peternakan Universitas Udayana, Paper submitted at Seminar Sapi Bali di Unud dalam rangka perayaan Dies Natalis Unud ke-47, 5-6 Oktober 2009, Denpasar, Bali, Indonesia (2009)

25. N. Rohmah, Y.S. Ondho, D. Samsudewa, Jur. Sains Peternakan Indonesia, 12, 3, 290298 (2017) 